TECHNICAL SCIENCES AND TECHNOLOGIES

УДК 629.735 .45

DOI: $10.25140 / 2411-5363-2019-3(17)-37-48$

Олег Шаповалов, Денис Колесник, Олег Пилипенко

\title{
ЗАСТОСОВУВАНІСТЬ І ЗАЛЕЖНІСТЬ ПАРАМЕТРІВ ЗУБЧАСТИХ ПЕРЕДАЧ АВІАЦІЙНИХ РЕДУКТОРІВ ВІД ТЕХНОЛОГІЧНИХ ПРОЦЕСІВ ЇХ ВИГОТОВЛЕННЯ
}

Актуальність теми дослідження. Проблема надійності роботи зубчастих передач пов'язана з технологією йх виготовлення. Вирішення пов'язаних з иією проблемою завдань засноване на ретельному вивченні й використанні взаємозв 'язку конструкторських і технологічних чинників з експлуатаційними показниками надійності зубчастих передач. Особлива увага при цьому приділяється управлінню технологічними прочесами виготовлення зубчастих коліс, наданню робочим поверхням зубиів необхідних фізико-механічних властивостей і забезпеченню заданих показників точності спряження.

Постановка проблеми. Виявлення можливості збільшення ресурсів зубчастих передач, зокрема головного, проміжного та хвостового редукторів вертольотів Мі-8 та їх модифікаиій.

Аналіз останніх досліджень і публікацій. 3 аналізу літературних джерел можсна зробити висновок, що основними напрямами у виробництві зубчастих передач є підвищення силової напруженості та швидкохідності при зменшенні габаритів і маси, збільшенні термінів служби і ККД. Цьому сприяють сучасні досягнення у сфері металознавства і термічної обробки, які забезпечують істотне підвищення згинальної і контактної міцності зубиів $i$, отже, підвищення їх питомих навантажень.

Виділення недосліджених частин загальної проблеми. 3в'язок параметрів застосовуваних зубчастих передач авіаційних редукторів із технологічними прочесами їх виготовлення.

Мета статті. Розглянути застосовуваність зубчастих передач авіачійних редукторів $і$ залежність їх параметрів від технологічних прочесів виготовлення.

Виклад основного матеріалу. Розглянуті застосовуваність зубчастих передач авіаиійних редукторів, вплив технологічних прочесів на доопрацювання зубчастих передач на більший ресурс, підвищення витривалості зубиів при згині, вплив поверхневої деформаиії, електрополірування, віброшліфування, деформаційного старіння на контактну витривалість і довговічність

Висновок відповідно до статті. Наявний позитивний досвід експлуатаиії ииліндричних $і$ конічних зубчастих коліс свідчить про ефективність застосування розглянутих технологічних процесів підвищення витривалості зубиів при згині, вплив поверхневої деформації, електрополірування, віброшліфування, деформаційного старіння на контактну витривалість і довговічність $i$, у кінщевому підсумку, на підвищення ресурсу авіачійних редукторів.

Ключові слова: зубчасті передачі авіаційних редукторів; застосовуваність; технологічні процеси виготовлення для підвищення ресурсу.

Рис.: 5. Табл.: 4. Бібл.: 13.

Актуальність теми дослідження. Проблема надійності роботи зубчастих передач пов'язана $з$ технологією їх виготовлення [1]. Вирішення пов'язаних з цією проблемою завдань засноване на ретельному вивченні й використанні взаємозв'язку конструкторських і технологічних чинників з експлуатаційними показниками надійності зубчастих передач. Особлива увага при цьому приділяється управлінню технологічними процесами виготовлення зубчастих коліс, наданню робочим поверхням зубців необхідних фізико-механічних властивостей і забезпеченню заданих показників точності спряження [2]. Зубчасті колеса останніх ступенів редукторів вертольоту [3] мають порівняно невеликі колові швидкості $(15-20 \mathrm{~m} / \mathrm{c})$ i їх напрацювання за увесь ресурс не перевищує $10^{9}$ циклів навантажень. Лише $20 \%$ циліндричних зубчастих коліс працюють із коловими швидкостями від 20 до $100 \mathrm{~m} / \mathrm{c}$ і більше та близько половини застосовуваних конічних зубчастих передач - зі швидкостями від 35 до 100 м/с і більше [1].

Основною особливістю авіаційних зубчастих коліс $\epsilon$ їхня мала відносна маса й ажурність конструкцій. Розподіл маси по деталях і вузлах головних редукторів вертольотів наведений в таблиці 1 [1].

Як бачимо, найбільшу масу (від $1 / 4$ до $1 / 3$ маси всього редуктора) мають зубчасті колеса основного кінематичного ланцюга і шестерні приводів.

В авіаційних редукторах переважна більшість (близько 97 \%) циліндричних зубчастих передач виготовляється прямозубими і близько половини конічних коліс - iз круговими (спіральними) зубцями.

( Шаповалов О. Л., Колесник Д. М., Пилипенко О. І., 2019 
Розподіл маси по деталях і вузлах головних редукторів

\begin{tabular}{|c|c|c|c|c|c|}
\hline \multirow{2}{*}{$\begin{array}{c}\text { Найменування деталі } \\
\text { або вузла }\end{array}$} & \multicolumn{5}{|c|}{ Маса деталі або вузла, кг (\%) } \\
\cline { 2 - 6 } & ВР-2Б & P-5 & ВР-8А & P-7 & P-26 \\
\hline $\begin{array}{c}\text { Шестерні основного кінематичного } \\
\text { ланцюга }\end{array}$ & $80,7(28,3)$ & $154,0(33,0)$ & $215,0(28,7)$ & $810,2(25,3)$ & $45,8(22,8)$ \\
\hline Шестерні приводів & $5,4(1,9)$ & $10,0(2,0)$ & $14,4(1,9)$ & $32,5(1,0)$ & $5,0(2,5)$ \\
\hline $\begin{array}{c}\text { Підшипники основного } \\
\text { кінематичного ланцюга }\end{array}$ & $43,8(15,4)$ & $43,2(9,2)$ & $101,0(13,4)$ & $450,4(14,1)$ & $21,0(10,5)$ \\
\hline Підшипники приводів & $2,1(0,7)$ & - & $9,2(1,2)$ & $25,0(0,9)$ & $1,0(0,5)$ \\
\hline Корпус перебору і сателітів (водило) & - & $45,3(9,5)$ & $63,2(8,4)$ & $205,0(6,5)$ & $7,2(3,6)$ \\
\hline Вал несучих гвинтів & $31,3(11,0)$ & $75,0(16,0)$ & $108,0(14,4)$ & $532,0(16,6)$ & $42,9(21,4)$ \\
\hline Вал основного кінематичного & & - & & & \\
ланцюга & $10,2(3,6)$ & - & $16,8(2,2)$ & $74,9(2,3)$ & $2,5(1,3)$ \\
\hline Кріпильні вироби & $21,4(7,5)$ & - & $31,5(4,2)$ & - & $5,4(2,7)$ \\
\hline Корпусне литво & $61,2(21,4)$ & $70,0(15,0)$ & $133,0(17,7)$ & $580,0(18,1)$ & $42,2(21,0)$ \\
\hline Муфта вільного ходу & $7,8(2,3)$ & - & $11,1(1,5)$ & $95,0(3,0)$ & - \\
\hline Маслосистема і агрегати & $11,5(4,0)$ & - & $23,3(3,1)$ & $96,0(3,0)$ & $1,9(0,9)$ \\
\hline Сумарний \% шестерень & 30,2 & 35,0 & 30,6 & 26,3 & 25,3 \\
\hline
\end{tabular}

Абсолютна більшість високонапружених зубчастих передач має кут зачеплення $\alpha_{w}>20^{0}$, який є стандартним кутом зачеплення в загальному машинобудуванні. Зазвичай в одній ступені редуктора або привода передавальне число $u \leq 4$, а кількість зубців $z \leq 20$ застосовуються лише у $5 \%$ всіх типорозмірів зубчастих коліс авіаційної техніки. Здебільшого 50 \% зубчастих коліс зовнішнього зачеплення мають $25 \leq$ $z \leq 45$, а внутрішнього зачеплення $-81 \leq z \leq 127$. Що стосується модулів зачеплення, то вони розподіляються в межах $m=2,25 \ldots 8$ мм, причому близько $40 \%$ типорозмірів зубчастих коліс мають $3 \leq m \leq 5$ мм [1].

Конструктивними параметрами зубчастого колеса, що впливають безпосередньо на міцність, є коефіцієнти $\psi_{a w}=\frac{b_{w}}{a_{w}}$ і $\psi_{d}=\frac{b_{w}}{m z}=\frac{\psi_{m}}{z}$, де $\psi_{m}=\frac{b_{w}}{m}$, де $a_{w}, b_{w}-$ міжосьова відстань і ширина коліс відповідно.

Коефіцієнт $\psi_{a w}$ відображає вплив геометричних параметрів на контактну міцність, а коефіцієнт $\psi_{d}-$ на деформацію кручення тіла зубчастого колеса. Ця деформація впливає на нерівномірність розподілу навантаження по довжині контактних ліній. 3 точністю до $\cos \alpha \sec a_{w}$ можна приймати, що $\psi_{d}=0,5(1+u) \psi_{a w}$.

Результати статистичної обробки даних про застосовуваність високонапружених циліндричних коліс за параметром $\psi_{a w}$ свідчать, що розподіл цього параметра відповідає нормальному закону і лежить у межах $0,08 \leq \psi_{a w} \leq 0,45$, причому медіана розподілу дорівнює 0,25 [1].

Дуже близький до нормального закону розподілу типорозмірів зубчастих коліс і параметр $\psi_{d}$, що лежить у межах від 0,08 до 0,88 з медіаною 0,3.

Застосовуваність зубчастих коліс за параметром $\psi_{m}$ теж близька до нормального закону розподілу, причому $6,55 \leq \psi_{m} \leq 14,5$, медіана 10 [1]. Отже, авіаційні циліндричні зубчасті колеса треба віднести до категорії коліс із вузьким зубчастим вінцем. У зубчастих передач, складених із таких коліс, нерівномірність розподілу навантаження по дов- 
TECHNICAL SCIENCES AND TECHNOLOGIES

жині контактних ліній, переважно, не обмежує несучу здатність таких передач. Проте під час розрахунків на міцність завжди враховують деформацію тіла колеса залежно від місця прикладання і напрямку діючого силового потоку. Крім того, у конструкціях авіаційних редукторів і приводів прагнуть уникати консольного розташування зубчастих коліс.

У 70 \% зубчастих коліс $\psi_{\text {мm }}=\frac{L}{d_{\text {вал }}} \leq 1$, де $L$ - довжина маточини; $d_{\text {вал }}$ - діаметр посадкового отвору зубчастого колеса. Інтервал розподілу параметра $\psi_{L}=\frac{b_{w}}{L}$ становить $0,1 \leq \psi_{L} \leq 2,3$, де медіана - 0,7 [1]. Між коефіцієнтами $\psi_{\text {мm }}$ і $\psi_{L}$ існує статистичний зв'язок, що записується у вигляді рівняння регресії: $\psi_{\text {мm }}=1,614-1,113 \psi_{L}$.

Ширина зубчастого вінця у конічних колесах зі спіральними зубцями зазвичай лежить у діапазоні $0,37 l \geq b \geq 0,25 l$, де $l$ - довжина твірної ділильного конуса. У таких передач напрямок спіралі повинен забезпечувати виникнення сили, що буде виштовхувати спряжені колеса із зачеплення.

За даними журналу Gear Technology [2; 4], який у 2011 р. провів опитування виробників зубчастих коліс щодо стану технологій виготовлення зубчастих передач, методи виробництва поділилися таким чином (рис. 1).



Рис. 1. Класифікація методів виробництва зубчастих коліс

Дослідження технологічного забезпечення надійності зубчастих коліс дозволяє встановити такі критерії оцінки ефективності виготовлення, представлені в табл. 2 [2].

У табл. 2: $f p b$ - відхилення зубчастого колеса; $f_{f r}$ - похибка профілю зуба; $F_{p r}$ - накопичена похибка кроку зубчастого колеса; $F_{r r}$ - радіальне биття зубчастого вінця; $F_{U w r}-$ коливання довжини загальної нормалі; $F_{\beta r}$ - похибка напрямку зуба; $F_{s h r}$ - відхилення 
відносних розмірів сумарної зони дотику; $j_{n, \min }-$ гарантований бічний зазор; $E_{M s}, T_{M}-$ найменше відхилення розміру по роликах і допуск [5].

Таблиця 2

Критерії оцінки ефективності виготовлення зубчастих коліс

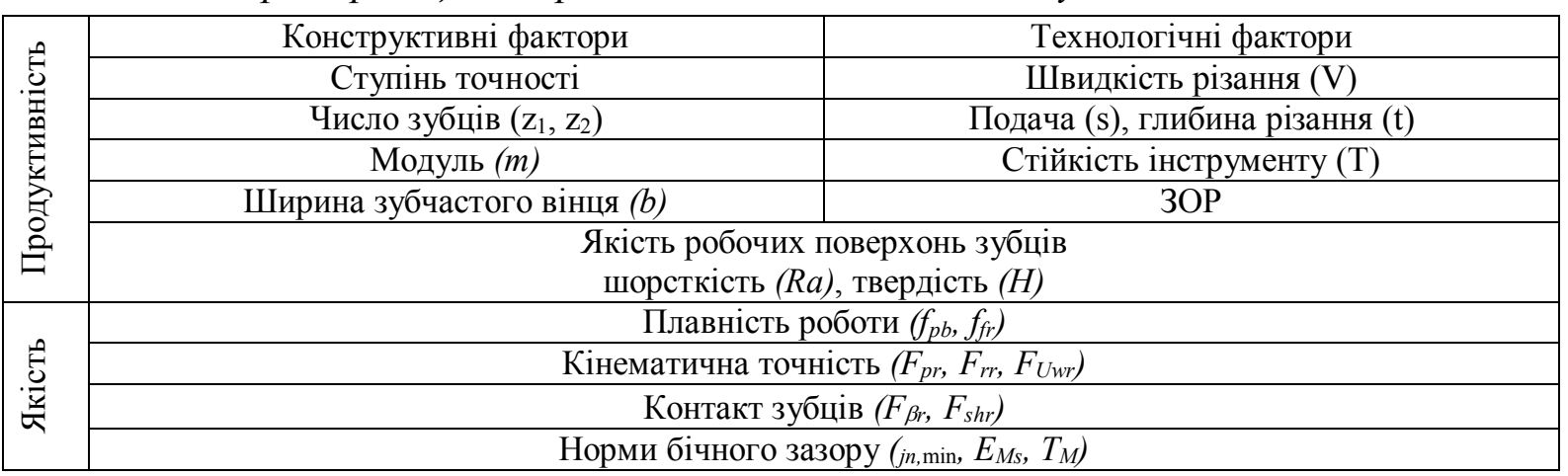

Усі способи поверхневої обробки стальних деталей машин, за допомогою яких можна керувати міцністю, можна поділити на такі групи [2]: технологічні (різання, чистова обробка), механічні (обкочування роликами, обдування дробом), термічні (індукційне нагрівання струмами високої частоти), хіміко-термічні (цементування, азотування).

Основними напрямками у виробництві зубчастих передач $є$ підвищення силової напруженості та швидкохідності при зменшенні габаритів і маси, збільшенні термінів служби та ККД. Цьому сприяють сучасні досягнення у сфері металознавства й термічної обробки, які забезпечують суттєве підвищення згинальної та контактної міцності зубців i, отже, підвищення питомих навантажень на зубці [6]. Наприклад, прямозуба авіаційна зубчаста передача зі сталі типу $12 \mathrm{X} 2 \mathrm{H} 4 \mathrm{~A}-Ш$ працює при допустимому рівні контактних напружень $\sigma$ нp $=1500$ МПа при $\mathrm{N}_{L}=5 \cdot 10^{7}$ циклів, границя згинальної витривалості $\sigma \quad F=950$ МПа при базовому числі циклів $N_{F 0}=4 \cdot 10^{6}[7]$.

Проводяться роботи, скеровані на те, щоб дифузійні покриття зубчастих коліс нового покоління відповідали таким значенням експлуатаційних властивостей: границя контактної витривалості в зоні зачеплення - 1500-2000 МПа; границя витривалості при згині, що контролюється в основі зуба, - 900-1200 МПа; робоча температура поверхонь зубчастих коліс - понад $350-450{ }^{\circ} \mathrm{C}$; температура миттєвих спалахів $-500-800{ }^{\circ} \mathrm{C}$ і більше.

При виробництві редукторів авіаційної техніки використовують евольвентні циліндричні прямозубі зубчасті колеса із зовнішнім зачепленням середнього модуля (від 2 до 6 мм) з цементованих (12Х2Н4A, 20Х3МВФ та ін.) і азотованих (18X2Н4MА 40ХНМА,

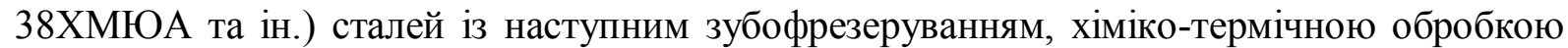
(цементація), зубошліфуванням або зубофрезеруванням, зубошліфуванням, азотуванням.

Авіаційні зубчасті колеса виготовляють 3 цементованих високолегованих сталей електрошлакового або вакуумного переплаву. Вони піддаються складній хімікотермічній обробці (загартування, обробка холодом, відпуск, цементація, азотування тощо), у результаті якої мають твердість поверхні не нижче $H R C 60$ при твердості серцевини $H R C 30 \ldots 42$ [2]. При цьому суворо регламентується відсотковий вміст вуглецю в поверхневому шарі, однорідність і дрібнозернистисть структури, глибина хімікотермічного шару, механічні властивості та їх ізотропність. Особливо оцінюються величина й характер розподілу залишкових стискаючих напружень.

Як цементовані сталі застосовуються 12Х2Н4А-Ш, 14ХГСН2МА-Ш, 30Х2Н2ВФМАШ, 20ХЗМВФА та інші. Ці сталі містять менше нікелю або є безнікелевими, більш стійкі 
TECHNICAL SCIENCES AND TECHNOLOGIES

проти заїдань, менш чутливі до припалів. Із цих сталей виготовляють не менше як $3 / 4$ всіх авіаційних зубчастих коліс i, зокрема, зубчасті колеса головних редукторів вертольотів.

Азотуванню підлягають здебільшого зубчасті колеса планетарних редукторів, таких, наприклад, як епіцикли, для чого застосовують сталь 38ХМЮА.

Слід зазначити, що припуск на шліфування поверхонь зубців повинен гарантувати отримання необхідної товщини зміцненого шару з урахуванням деформацій під час цементування. В ідеальному випадку цей шар не є рівномірним, оскільки ніжка зуба деформується більше, ніж голівка.

Несуча здатність хіміко-термічно оброблених зубчастих коліс великою мірою визначається величиною наведених залишкових стискаючих напружень. Ці напруження, які виникають у поверхневому шарі, врівноважуються відносно невеликими розтягуючими напруженнями в серцевині зуба, їх найбільша величина не перевищує $\sigma<1,15 \sigma_{T}$.

У процесі зубошліфування виводяться неточності зубофрезерування й основні деформації зубчастих коліс, пов'язані з термічною обробкою, а також знімається поверхневий шар із дефектами термообробки. Під дією високих температур відбуваються вторинні структурні зміни в матеріалі, що впливають на виникнення залишкових розтягуючих напружень. Мікроструктурні зміни у сталі, що відбуваються при підвищених режимах шліфування, призводять до так званих припалів.

Для збільшення надійності та несучої здатності зубчастих коліс їхні зубці виготовляють з піднутреною нешліфованою основою, шліфуванню піддають тільки евольвентний профіль зубців.

Значна частина авіаційних зубчастих коліс має евольвентну поверхню по $7 \ldots 8$ класу шорсткості за ГОСТ 2789-73, риски якої мають вигляд сітки. Така форма мікронерівностей має місце при шліфуванні зубчастих коліс на верстатах фірми «Мааг» 3 кутом встановлення шліфувального круга $\alpha_{ш}=15^{0}$ або $20^{0}$. При цьому припускають, що зубчасті колеса працюють в умовах граничного змащування й орієнтована таким чином шорсткість сприяє утриманню масляного шару.

У зв'язку з доопрацюванням (доводкою) зубчастих передач на більший ресурс стала помітна тенденція переходу на «безперервне» шліфування, що має місце при нульовій - паралельній - установці робочих граней шліфувального круга. В основу цього методу шліфування, що дозволяє підвищити шорсткість поверхні до 9-го класу за ГОСТ 2789-73, покладено припущення про існування гідродинамічної масляної плівки.

Досвід доопрацювання авіаційних двигунів на більший ресурс підтверджує високу працездатність зубчастих коліс із шорсткістю, що відповідає $9 \ldots 10$ класу, причому поверхню з 10 класом шорсткості отримують зубохонінгуванням. Під час зубохонінгування зменшують похибки основного кроку при зніманні металу в 5..6 мкм. Шорсткість перехідної поверхні звичайно на $1 . .2$ класи нижче, ніж шорсткість евольвентної поверхні, проте при тонких ободах чистота перехідної поверхні досягає 10..11 класу шорсткості. У цьому випадку, враховуючи вплив чистоти поверхні на опір згинальної втоми, застосовують ретельне полірування перехідної поверхні [1].

Іноді як остаточну операцію з доопрацювання евольвентної поверхні зуба застосовують електрополірування, що дозволяє отримати 9-й клас шорсткості. Недоліки електрополірування компенсуються дробоструменевим наклепом поверхні. Замість електрополірування як фінішну операцію застосовують притирання зубчастих коліс графітизованим перлітним чавунним притиром із пастами. Під час притирання знімається шар 20...30 мкм і переважно виправляються похибки основного кроку й напрямку зуба. Хонінгуванням або притиранням знімають тонкий дефектний шар, що залишився після термообробки, шліфування, травлення зубчастих коліс з метою винайдення припалів. Різні методи пластичного деформування також $є$ завершальною операцією для підвищення якості зубчастих коліс. 
TECHNICAL SCIENCES AND TECHNOLOGIES

Кінематограми на рис. 2, а і $б$ демонструють зміну спряженості тієї ж самої пари зубчастих коліс, виготовлених на різних верстатах [1]. Перша пара виготовлена на верстаті KS-42 фірми «Мааг», що працює за схемою плоского виробляючого колеса, а друга - на верстаті 5870М конструкції ЭНИМС, побудованого за схемою плосковершинного виробляючого колеса. Це приклад виготовлення за одним кресленням різних коліс. Кінематограма рис. 2, в у порівнянні з 2, б показує, наскільки сильно впливає кількість зубців у зачепленні на ступінь неспряженості при обробці за схемою плосковершинного виробляючого колеса.
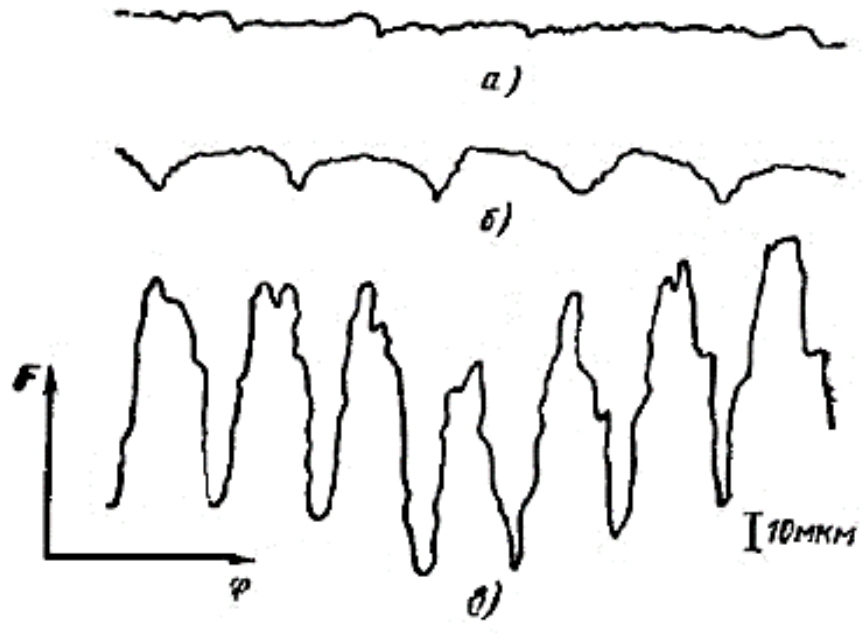

Рис. 2. Кінематичні похибки конічних прямозубих пар:

$a$ - пара при $m=6$ мм, $z_{1}=32, z_{2}=47, \alpha=20^{\circ}$, иліфована на верстаті фірми «Мааг» KS-42; б- та ж сама пара, шліфована на верстаті 5870M; в- пара при $m=5 \mathrm{Mм}, z_{1}=15$,

$z_{2}=18, \alpha=20^{\circ}$, оброблена за схемою плосковершинного колеса

Спряжені конічні зачеплення в навантажених передачах непрацездатні через деформації власне коліс, їх переміщень за рахунок деформації підшипників і корпусів, похибок виготовлення та температурних деформацій. У таких зачепленнях контакт під навантаженням виходить за кромку, і передача стає неможливою. У конструкціях навантажених передач застосовується виключно неспряжені, модифіковані по профілю і лініям зубців зачеплення (з локалізованою плямою контакту).

Під час виготовлення високонапружених зубчастих коліс визнано доцільним застосовувати тепломіцні, менш схильні до утворення припалів, сталі 12Х2НВФА, 20Х3МВФА, 16ХЗНВМФБЦ і особливо 13ХЗНВМ2Ф-Ш. Вони допускають більш продуктивний режим шліфування, що знижує час на обробку одного зуба на $30 \ldots 50 \%$, у порівнянні зі сталлю 12Х2Н4А [1].

Зміцнення зубців коліс здійснюється обкочуванням роликами [8] або валкамишестернями [9] і обдувкою дробом [10;11]. Обкочування валками-шестернями дозволяє зміцнити зубці по всьому профілю й воно більш продуктивне, ніж обкочування роликами, але вимагає застосування спеціального обладнання та профільованого інструменту. Збільшення границі витривалості після зміцнення дробом для сталі після відпалювання становить $9 \%$, після покращення - $18 \%$, після загартування і відпуску - 48 \%.

У цементованих сталей залишкові напруження стиску після поверхневого пластичного деформування можуть перевищувати 1000 МПа, змінюючись більш суттєво (на сотні відсотків), ніж інші властивості (наприклад, твердість), що визначає для них високу ефективність деформаційного зміцнення. Високий градієнт залишкових напружень стиску, зменшуючи величину результуючого напруження розтягу в поверхні в небезпечному перерізі основи зуба, зміщує місце руйнування в приповерхневий шар. У результаті поверхневий наклеп знижує чутливість цементованої сталі до концентрато- 
TECHNICAL SCIENCES AND TECHNOLOGIES

рів напружень, дозволяючи тим самим найбільш повно використати іiі високоміцний стан, підвищити надійність роботи та несучу здатність зубчастих коліс.

Підвищення витривалості зубців при згині залежить від методу поверхневого пластичного деформування, режимів наклепу, початкового стану поверхні. Обкочування роликами методом Кузьміна [12] підвищує границю витривалості зубців при згині цементованих коліс на $30 . .50$ \% і суттєво збільшує їх довговічність (рис. 3) [1].

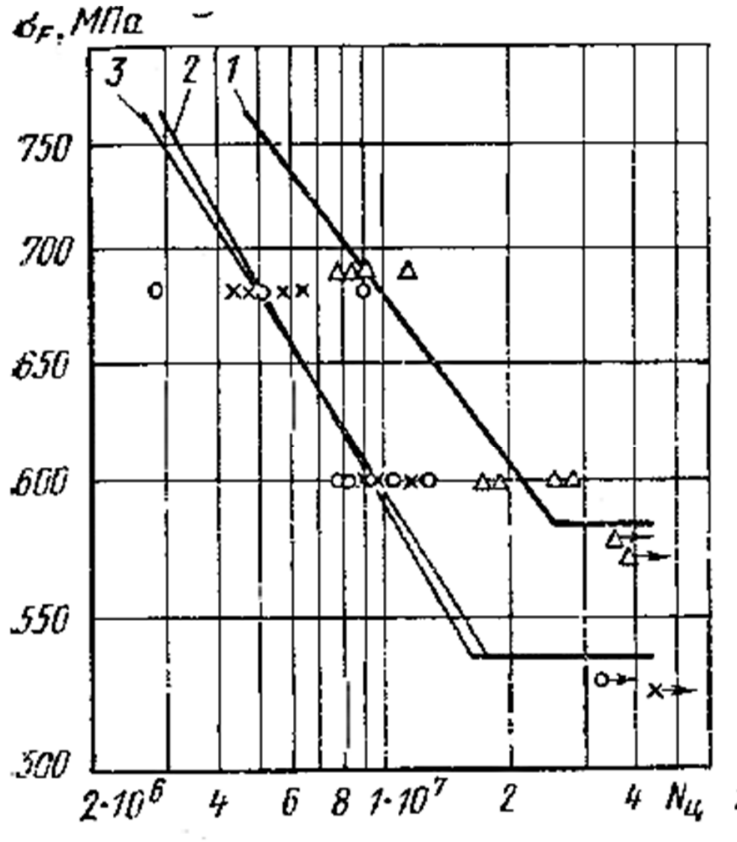

a)

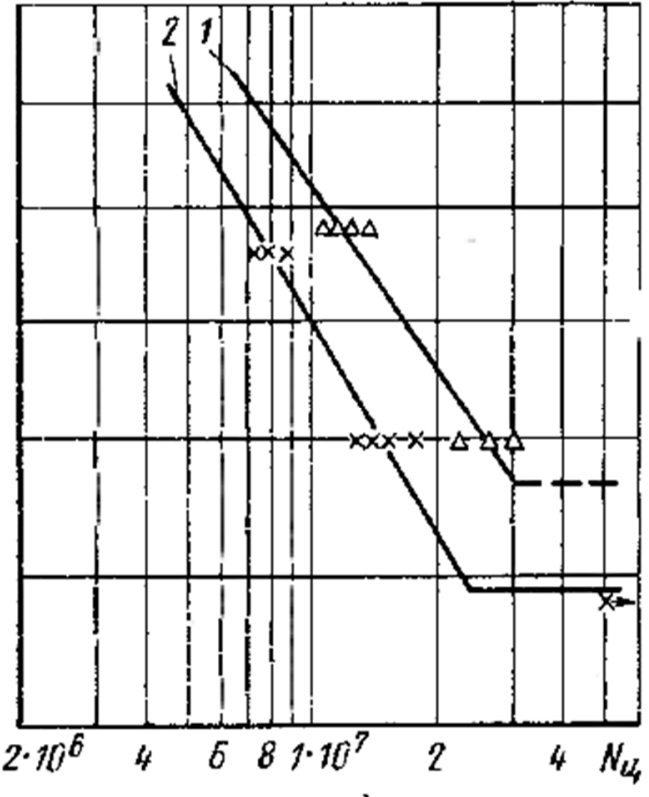

6) (.)

Рис. 3. Криві витривалості зубиів коліс при згині:

а-зі сталі 12Х2Н4А; б - зі сталі $12 Х 2 Н В Ф А$; 1 - зубчасті колеса з нешліфованою піднутреною основою зубиів; 2 - із нешліфованою основою з уступом; 3 - зі иліфованою основою зубиів

На рис. 4 представлені границя витривалості й довговічність сталі 12Х2Н4А залежно від часу обробки і кінетичної енергії дробу при пневмодробоструменевому зміцненні.

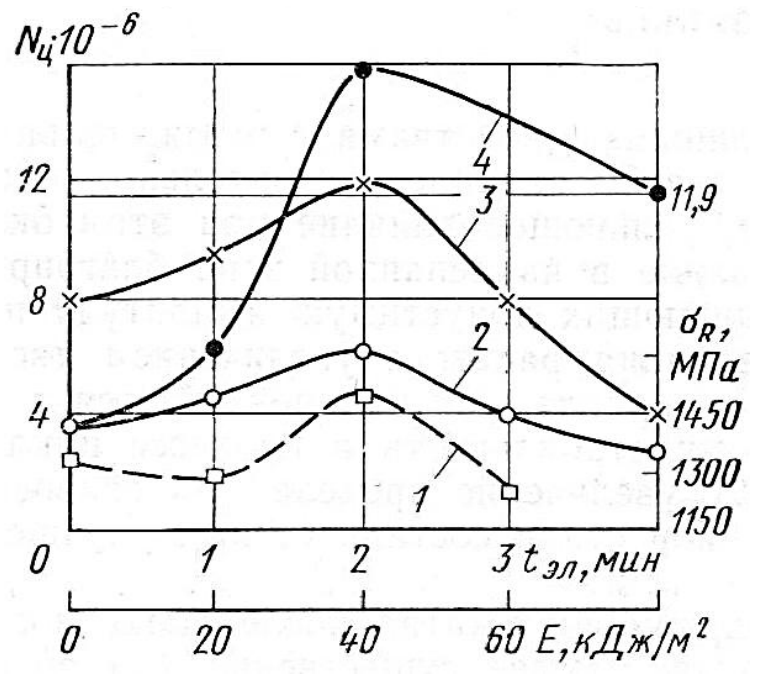

Рис. 4. Границя контактної витривалості $\sigma_{R}(1)$ і довговічність $N_{L}(2 \ldots 4)$

при напруженні в контакті $\sigma_{Z \max }=1820$ МПа сталі $12 X 2 H 4 A$ залежно від часу обробки $t_{э n}$ i кінетичної енергї дробу Е при пневмодробоструменевому зміцненні:

$1 . . .3$ - наклеп і натуральне старіння; наклеп і старіння при $t=130^{\circ} \mathrm{C}$ на протязі 2 год;

1, 2, 4- товщина цุементованого шару 1,0 мм; 3 - товщчина ичементованого шару 1,3 мм 
TECHNICAL SCIENCES AND TECHNOLOGIES

Границя витривалості при згині цементованої сталі 20Х2Н4А зростає з 838 МПа до 970 МПа під час обкочування роликами по мірі зростання напруження в контакті до 5000 МПа. При більших контактних напруженнях вона знижується [12].

Висока ефективність гідродробоструменевого зміцнення зубчастих коліс ( $m=3$ мм, $z=50, \alpha=25^{0}, b=8$ мм) 3 нешліфованою піднутреною основою зубців зі сталі $20 Х 3 М В Ф-Ш ~(H R C \geq 58)$ встановлена в [13]. Після обкочування кожного зуба протягом 3 хв кульками діаметром 1,6 мм під тиском трансформаторного масла 0,8 МПа границя витривалості зубців при згині в порівнянні з незміцненим станом збільшується 3 480 до $680 \mathrm{MПа,} \mathrm{тобто} \mathrm{на} \cong 43 \%$. Обробка дробом нітроцементованих коліс збільшує витривалість зубців при згині у $3 . .5$ разів.

Вплив поверхневого деформування на контактну витривалість менш суттєвий, оскільки залишкові напруження стиску не спричиняють на неї такого вирішального впливу, як на витривалість зубців при згині. Інші властивості змінюються менш суттєво і до того ж іноді в небажаному напрямку (наприклад, підвищення шорсткості під час наклепу дробом). Шорсткість поверхні залежить від способу зміщнення, часу наклепу та початкової шорсткості. Додаткові операції - електрополірування або віброшліфування - покращують шорсткість поверхні: знижують висоту мікронерівностей, змінюють характер мікрорельєфу, згладжуючи гострі виступи і западини. Вплив способу зміцнення стає непомітним.

Для сталей з високою поверхневою твердістю вважається більш переважним застосування алмазного вигладжування замість обкочування роликами. Вигладжування алмазним інструментом радіусом 1,5 мм дозволяє при невисокому зусиллі в $100 \ldots 300$ Н створювати високий тиск у контакті в 7000...10040 МПа і тим самим значну пластичну деформацію, що розповсюджується на більшу глибину від поверхні, ніж під час наклепу дробом (рис. 5). У результаті зміцнений шар має більшу товщину (0,3 ..0,4 мм), а максимум залишкових напружень зміщений в глибину шару й величина напружень у поверхні менше. При зусиллях вигладжування $300 \mathrm{H}$ і більше залишкові напруження переходять в розтягуючі. Твердість поверхні підвищується зі збільшенням зусилля вигладжування до $200 \mathrm{H}$ і помітно знижується при $P>300 \mathrm{H}$.

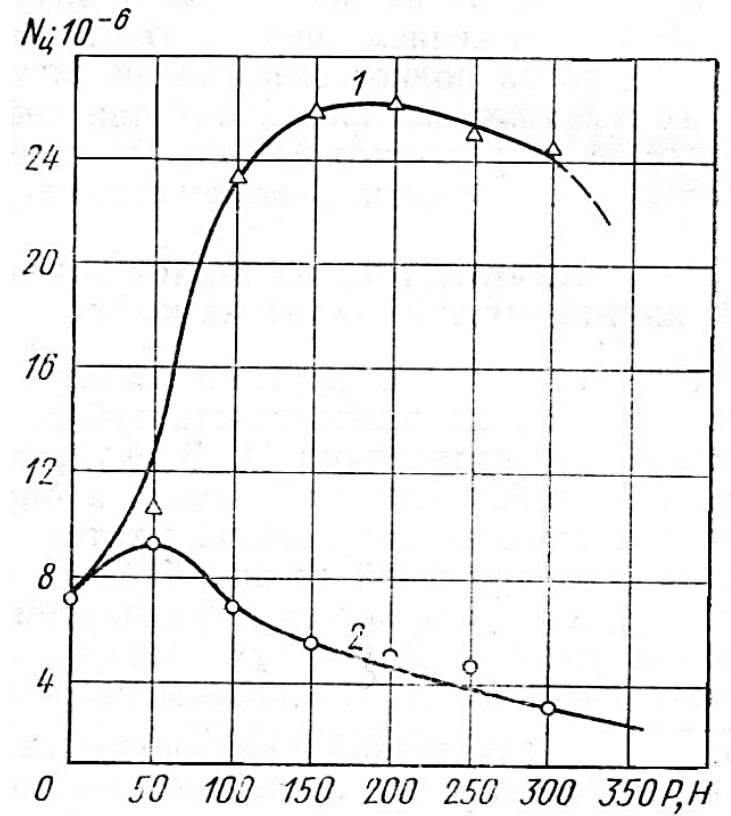


від зусилля вигладжування $P(S=0,04$ мм/об; $v=0,8 \mathrm{M} / c)$ :

1 - вигладжування і старіння при $160^{\circ} \mathrm{C}, 2$ год; 2 - вигладжування 
TECHNICAL SCIENCES AND TECHNOLOGIES

Деформаційне старіння (низькотемпературний відпуск) після поверхневого пластичного деформування додатково покращує тонку структуру деформованого матеріалу і підвищує контактну витривалість цементованих сталей [1]. Деформаційне старіння знижує мікровикривлення кристалічної решітки і призводить до більш високого ступеня закріплення дислокацій, ніж натуральне старіння.

Найменшу рухливість дефектів викликає старіння протягом 2 год. при температурі $130{ }^{\circ} \mathrm{C}$ для сталі 12 Х2Н4A і $160{ }^{\circ} \mathrm{C}$ для сталей 12Х2НВФА і 20Х3МВФА. При більш високих температурах і витримках розвивається перестарювання, що призводить до утворення менш стабільної дислокаційної структури. Твердість поверхні та залишкові мікронапруження під час старіння змінюються незначно. Старіння після раціональних режимів наклепу дробом підвищують довговічність сталі 12Х2Н4А в 2,0...3,5 раза, а після алмазного вигладжування - в $3 . .5$ разів. У табл. 3 представлена контактна витривалість сталі 12Х2НВФА після зміцнення різними способами [1].

Таблиця 3

Контактна витривалість сталі $12 X 2 Н В Ф А$ після змічннення при $E=40 \kappa Д ж / м^{2}$ різними способами



Вплив електрополірування й віброшліфування на контактну витривалість. Наклеп дробом визнано доцільним суміщати з електрополіруванням або віброшліфуванням робочих поверхонь зубців, причому електрополірування можна проводити або до, або після наклепу дробом. Електрополірування як шліфованих, так і зміцнених дробом роликових зразків підвищує контактну витривалість у 2,0...2,5 раза, а віброшліфування при жорсткому зачепленні деталей - у 11,5 раза (табл. 4).

Таблиця 4

Вплив технології обробки поверхні на контактну витривалість сталі $12 X 2 Н В Ф А$

\begin{tabular}{|c|c|c|}
\hline Варіант & Технологія фінішної обробки & $\begin{array}{l}\text { Довговічність, млн циклів } \\
\qquad\left(\sigma_{Z \text { max }}=2160 M П a\right)\end{array}$ \\
\hline I & Шліфування & 3,3 \\
\hline II & $\begin{array}{l}\text { Шліфування }+ \text { електрополірування }+ \text { наклеп дробом (пневмо- } \\
\text { дробоструменеве зміцнення, } t_{\text {эn }}=3 \text { xв) }\end{array}$ & 3,6 \\
\hline III & $\begin{array}{l}\text { Шліфування }+ \text { електрополірування }+ \text { наклеп дробом (пневмо- } \\
\left.\text { дробоструменеве зміцнення, } t_{\text {эn }}=3 x 8\right)+ \text { додаткове старіння при } \\
t=160^{\circ} \mathrm{C}, 2 \text { год }\end{array}$ & 13,1 \\
\hline IV & $\begin{array}{l}\text { Шліфування + наклеп дробом (пневмодробоструменеве зміц- } \\
\text { нення, } t_{\text {эn }}=3 \text { xв) + електрополірування }\end{array}$ & 8,7 \\
\hline $\mathrm{V}$ & $\begin{array}{l}\text { Шліфування + наклеп дробом (пневмодробоструменеве зміц- } \\
\text { нення, } t_{\text {эn }}=3 \text { хв.) + електрополірування }+ \text { додаткове старіння } \\
\text { при } t=160^{\circ} \mathrm{C}, 2 \text { год }\end{array}$ & 16,8 \\
\hline
\end{tabular}


Збільшенню довговічності сприяє підвищення класу шорсткості, покращення однорідності іiї структури та властивостей. Крім того, електрополірування деформованої поверхні в результаті іiі розігріву викликає розвиток початкових стадій деформаційного старіння. 3 цієї причини його ефективно застосовувати після наклепу. Електрополірування після зміцнення дробом (варіант IV) у порівнянні з варіантами I і II підвищує довговічність у 2,4 раза. Старіння після наклепу й електрополірування (варіанти III i V) додатково збільшують довговічність.

Зміна контактної витривалості від режимів наклепу відбувається по-іншому, ніж для витривалості при згині, границя якої змінюється за кривою 3 «насиченням». Під час поверхневого дробоструменевого зміцнення контактна витривалість підвищується лише при одному (раціональному) режимі: час електрополірування $t_{e л}=2 \mathrm{xв}$, енергія деформу-

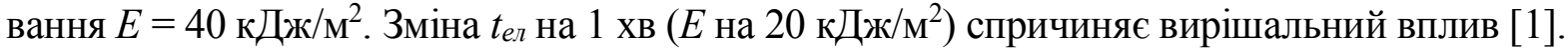

Твердість поверхні та залишкові напруження стиску набувають найбільших значень при $t_{\text {eл }}=4$ хв $(E=80$ кДж/м²), проте контактна витривалість при цьому режимі знижується у $1,5 \ldots 2,0$ рази. Аналогічна закономірність характерна для алмазного вигладжування і $є$ загальною для всіх методів поверхневого пластичного деформування.

Контактна витривалість при алмазному вигладжуванні підвищується лише при зміцненні зусиллям $50 \mathrm{H}\left(p_{0}=5540 \mathrm{MПа}\right)$. Збільшення зусилля вигладжування більше $100 \mathrm{H}$ призводить до зниження довговічності.

Висновки відповідно до статті. Наявний позитивний досвід експлуатації циліндричних і конічних зубчастих коліс свідчить про ефективність застосування розглянутих технологічних процесів підвищення витривалості зубців при згині, поверхневого деформування, електрополірування, віброшліфування, деформаційного старіння на контактну витривалість та довговічність i, в кінцевому підсумку, для підвищення ресурсу авіаційних редукторів.

\section{Список використаних джерел}

1. Авиационные зубчатые передачи и редукторы. Справочник / под ред. Э. Б. Вулгакова. Москва: Машиностроение. 1982. 375 с.

2. Жукова С. И. Разработка метода технологического обеспечения противозадирной стойкости в кромочной зоне контактирования эвольвентных цилиндрических зубчатых колёс редукторов газотурбинных двигателей: дис. ... канд. техн. наук / Рыбинский государственный авиационный технический университет имени П. А. Соловьева. Рыбинск, 2018. 166 с.

3. Шаповалов О., Колесник Д., Пилипенко О. Конструкції, кінематичні схеми та технічні характеристики вертольотних редукторів. Технічні науки та технологіï. 2018. № 2(12). С. 34-48.

4. Shen T., Krantz T., Sebastian J. Advanced Gear Alloys for Ultra High Strength Applications. Офиииальный сайт NASA. 2011. URL: http://ntrshttp://ntrs.nasa.gov/archive/nasa/casi.ntrs.nasa.gov/ 20110023751.pdf.

5. ГОСТ 1643-81. Основные нормы взаимозаменяемости. Передачи зубчатые цилиндрические. Допуски. [Взамен ГОСТ 1643-72; дата введения 1981-07-01]. Москва: Изд-во стандартов, 1981. 75 с.

6. Маликов А. А., Сидоркин А. В., Ямников А. С. Инновационные технологии обработки зубьев цилиндрических колёс: монография. Тула: Изд-во ТулГУ, 2011. 335 с.

7. Поклад В. А., Яковлев В. А., Дорофеев В. Л. Обеспечение работоспособности центрального привода двигателей в условиях повышенных вибраций. Авиационно-космическая техника и технология. 2008. № 9. С. 72-75.

8. Балтер М. А. Упрочнение деталей машин. Москва: Машиностроение, 1978. 184 с.

9. Орлов В. В., Юдин Д. А., Петраков А. П. О деформированном поверхностном упрочнении зубчатых колес. Вестник машиностроения. 1979. № 1. С. 17-19.

10. Морозов В. И., Шубина Н. Б. Наклеп дробью тяжелонагруженных зубчатых колес. Москва: Машиностроение, 1972. 104 с.

11. Петрогов В. В. Гидродробеструйное упрочнение деталей и инструмента. Машиностроение. 1977. № 3. С. 47-50.

12. Кузьмин М. И. Упрочнение и отделка наклепыванием профиля зубьев шестерен. Повышение износостойкости и срока службы машин. Киев: Изд. АН УССР, 1960. Т. 2. С. 47-56. 
TECHNICAL SCIENCES AND TECHNOLOGIES

13. Иосилевич Г. Б., Беляев В. А., Точилкин А. А. Исследование изгибной усталостной прочности зубьев зубчатых колес, подвергнутых гидродробеструйной обработке. Труды УАИ. 1974. Вып. 78. С. 107-118.

\section{References}

1. Vulgakov, A. B. (Ed.) (1982). Aviazionnye zubchatye peredachi i reduktory [Aviation gearing and reducers]. Moscow: Mashinostroenie [in Russian].

2. Gukova, S. I. (2018). Razrabotka metoda technologicheskogo obespechenia protivozadirnoi stoikosti v kromochnoi zone kontaktirovania evolventnyh zilindricheskih zubchatyh koles reduktorov gazoturbinnyh dvigatelei [Development of method of the technological providing of antiscuff firmness is in the edge area of contact of involute cylindrical gear-wheels of reducing gears of turbo-engines] (Candidate's thesis). Rybinskii gosudarstvennyj aviazionnyi tehnicheskii universitet imeni P. A. Solovjeva, Rybinsk [in Russian].

3. Shapovalov, O., Kolesnik, D., Pilipenko, O. (2018). Konstruktsii, кinematychni shemy ta tehnichni kharakterystyky vertoliotnykh reduktoriv [Structures, kinematic schemes and technical characteristics of helicopter reducers]. Tekhnichni nauky ta tekhnolohii - Technical sciences and technologies, 2 (12), 34-48 [in Ukrainian].

4. Shen, T., Krantz, T., Sebastian, J. (2011). Advanced Gear Alloys for Ultra High Strength Applications. Official site NASA. Retrieved from http://ntrshttp://ntrs.nasa.gov/archive/nasa/casi.ntrs. nasa.gov/20110023751.pdf.

5. GOST 1643-81. Osnovnye normy vzaimozameniaemosti. Peredachi zubchatye zilindricheskie. Dopuski. [Basic norms of interchangeability. Transmissions toothed cylindrical. Admittances]. Moscow: Izd-vo standartov [in Russian].

6. Malikov, A. A., Sidorkin, A. V. Jamnikov, A. S. (2011). Innovazionnye tehnologii obrabotki zubiev zilindricheskih koles [Innovative technologies of treatment of teeth of cylindrical wheels]. Tula: Izd-vo TulGU [in Russian].

7. Poklad, V. A., Jakovlev, V. A., Doropheev, V. L. (2008). Obespechenie rabotosposobnosti zentralnogo privoda dvigatelei $\mathrm{v}$ usloviiakh povyshennykh vibrazii [Providing of capacity of central drive of engines in the conditions of enhanceable vibrations]. Aviatsionno-kosmicheskaia tekhnika $i$ tekhnologiia - Aerospace Engineering and Technology, 9, 72-75 [in Russian].

8. Balter, M. A. (1978). Uprochnenie detalej mashin [Work-hardening of machine elements]. Moscow: Mashinostroenie [in Russian].

9. Orlov, V. V., Judin, D. A., Petrakov, A. P. (1979). O dephormirovannom poverhnostnom uprochnenii zubchatykh koles [About the deformed superficial work-hardening of gear-wheels]. Vestnik mashinostroenia № 1. [in Russian].

10. Morozov, V. I., Shubina, N. B. (1972). Naklep drobiu tiazhelonagruzennyh zubchatykh koles [Riveting by the shot of heavy-loading gear-wheels]. Moscow: Mashinostroenie [in Russian].

11. Petrogov, V. V. (1977). Gidrodrobestruinoe uprochnenie detalei i instrumenta [Hydroshotblast work-hardening of parts and instrument]. Mashinostroenie - Engineering, 3, 47-50 [in Russian].

12. Kuzmin, M. I. (1960). Uprochnenie i otdelka naklepyvaniem prophilia zubiev shesteren [Workhardening and finishing by riveting on of profile of teeth of pinions]. Povyshenie iznosostojkosti i sroka sluzby mashyn - Increased wear and tear of machines. Kiev: Izd-vo AN USSR. Vol. 2, 47-56 [in Russian].

13. Iosilevich, G. B., Beljaev, V. A., Tochilkin, A. A. (1974). Issledovanie izgibnoj ustalostnoj prochnosti zubjev zubchstyh koles, podvergnutyh gidrodrobestrujnoj obrabotke. [Research of bending tireless resistance of teeth of gear-wheels, exposed to hydroshotblast treatment]. Trudy UAI-Proceedings of the AIM, 78, 107-118 [in Russian].

UDC 629.735.45

Oleg Shapovalov, Denis Kolesnik, Oleg Pilipenko

\section{APPLIED AND DEPENDENCE OF PARAMETERS OF GEARING OF AVIATION REDUCING GEARS FROM TECHNOLOGICAL PROCESSES THEIR MAKING}

Urgency of the research. The problem of reliability of work of gearing is closely related to technology of their making. Decision of the tasks related to this problem is based on a careful study and use of intercommunication of designer and tech- 
TECHNICAL SCIENCES AND TECHNOLOGIES

nological factors with operating reliability of gearing indexes. The special attention is here spared to the management by the technological processes of making of gear-wheels, to giving to the working surface of teeth necessary physical and mechanical properties and providing of the set indexes of exactness of interface.

Target setting. Exposure of possibility of increase of resource of gearing main, intermediate and tail reducing gears of helicopters of $\mathrm{Mu}-8$ and their modifications.

Actual scientific researches and issues analysis. It is possible to conclude from the analysis of literary sources, that basic directions in the production of gearing is an increase of power tension and high-speed at reduction of sizes and mass, increase of tenures of employment and efficiency. It is assisted by modern achievements in the areas of physical metallurgy and heat treatment, that provide the substantial increase of bending and contact resistance of teeth and, consequently, increase of their specific loading.

Uninvestigated parts of general matters defining. Association of parameters of the applied gearing of aviation reducing gears with the technological processes of their making.

The research objective. To consider applied of gearing of aviation reducing gears and dependence of their parameters from the technological processes of making.

The statement of basic materials. The applied of gearing of aviation reducing gears, influence of technological processes of revision of gearing is considered on a greater resource, increase of endurance of teeth at a bend, influence of superficial deformation, electro-polishing, vibration grinding, deformation aging on contact endurance and longevity.

Conclusion in accordance with the article. Existent positive experience of exploitation of cylindrical and conical gearwheels testifies to efficiency of application of the considered technological processes of increase of endurance of teeth at a bend, influence of superficial deformation, electro-polishing, vibration grinding, deformation aging on contact endurance and longevity and, in final analysis, - on the increases of resource of aviation reducing gears.

Keywords: gearing of aviation reducing gears; applied; technological processes of making for the increase of resource. Fig.: 5. Table: 4. References: 13.

Шаповалов Олег Леонідович - начальник відділу, Державний науково-дослідний інституг випробувань і сертифікації озброєння та військової техніки (вул. Стрілецька, 1, м. Чернігів, 14033, Україна).

Shapovalov Oleg - Head of Department, State Research Institute of Tests and Certification of Armament and Military Technique (1 Striletska Str., 14033 Chernihiv, Ukraine)

E-mail: ak1149cv@ukr.net

Колесник Денис Миколайович - начальник науково-дослідної лабораторії, Державний науково-дослідний інституг випробувань і сертифікації озброєння та військової техніки (вул. Стрілецька, 1, м. Чернігів, 14033, Україна).

Kolesnik Denis - Chief of research laboratory, State Research Institute of Tests and Certification of Armament and Military Technique (1 Striletska Str., 14033 Chernihiv, Ukraine).

E-mail: denis1971@ukr.net

Пилипенко Олег Іванович - доктор технічних наук, професор, керівник секції основ конструювання машин кафедри зварювального виробництва та автоматизованого проектування будівельних конструкцій, Чернігівський національний технологічний університет (вул. Шевченка, 95, м. Чернігів, 14035, Україна), провідний науковий співробітник, Державний науково-дослідний інститут випробувань і сертифікації озброєння та військової техніки (вул. Стрілецька, 1, м. Чернігів, 14033, Україна).

Pilipenko Oleg - Doctor of Technical Sciences, Professor, leader of the Fundamental Machine Design section, the Welding Technology and Automatized Projecting of Building Structures Department, Chernihiv National University of Technology (95 Shevchenka Str., 14035 Chernihiv, Ukraine), leading scientific coworker, State Research Institute of Tests and Certification of Armament and Military Technique (1 Striletska Str., 14033 Chernihiv, Ukraine).

E-mail: opilip@ukr.net

ORCID: http//orcid.org/0000-0003-0590-0107

Scopus Author ID: 16510833000

ResearcherID: G-2533-2016

Шаповалов О., Колесник Д., Пилипенко О. Застосовуваність і залежність параметрів зубчастих передач авіаційних редукторів від технологічних процесів їх виготовлення. Технічні науки та технологї̈. 2019. № 3 (17). С. 37-48. 